\title{
Bioethical committees and data protection issues in Poland Danuta Ligocka
}

\author{
Address: Nofer Institute of Occupational Medicine, 8 Teresy St., 91-348 Lodz, Poland \\ Email: Danuta Ligocka - ligocka@imp.lodz.pl
}

from Ethics and communication in human biomonitoring in Europe: results from preparation of pilot studies Copenhagen, Denmark. II-13 March 2007

Published: 5 June 2008

Environmental Health 2008, 7(Suppl I):S4 doi:10.II86/I476-069X-7-SI-S4

This article is available from: http://www.ehjournal.net/content/7/SI/S4

(c) 2008 Ligocka; licensee BioMed Central Ltd.

This is an open access article distributed under the terms of the Creative Commons Attribution License (http://creativecommons.org/licenses/by/2.0), which permits unrestricted use, distribution, and reproduction in any medium, provided the original work is properly cited.

\begin{abstract}
In Poland there are only Regional Bioethical Committees. Unlike most EU countries Poland has no coordinating centre on bioethics for human research. However, the Ministry of Health and Welfare has established a Bioethics Appeals Committee.

The functioning of the Bioethical Committees in Poland is regulated in detail by the Regulation of the Ministry of Health and Welfare of 1999. All regulations comply with important guidelines such as: the Helsinki Declaration, The Rules of Good Clinical Practice, EU Directives and legal regulations binding in Poland, mainly the Act of the Medical Doctor Profession and the Dentist Profession, as well as the Act of Pharmaceutical Law.

In the framework of the Human Biomonitoring Programme, the application for bioethical evaluation will be submitted to the Bioethical Committee at the Nofer Institute of Occupational Medicine in Lodz.

The data protection legislation in Poland according to the Act of the Protection of Personal Data of $29^{\text {th }}$ of August 1997 with latest amendments fulfils EU regulations. The Act also contains detailed provisions regarding the duties of the Inspector General for Data Protection. The paper presents data on the activities of the Bureau of the Inspector General for Personal Data Protection in 2005, 2006 and 2007.
\end{abstract}

\section{Bioethical Committees in Poland}

In Poland, a number of bodies responsible for dealing with ethical issues of research have been established. There are twenty Regional Ethics Committees for Animal Research coordinated by the National Ethics Committee for Animal Research.

Unlike other countries, Poland does not have a coordinating national centre for Bioethical Committees in human research. There are 54 independent Bioethical Commit- tees. The topics of applications submitted for ethical evaluation to the Bioethical Committees vary according to the research area of the institutions applying.

The Bioethical Committees are independent collegial bodies. The aim of their activity is to guarantee the rights, safety and welfare of the participants in medical research. The Committee safeguards the respect and dignity of a human being with higher priority than the scientific aims of the research. 
The functioning of Bioethical Committees in Poland is regulated by the Act of the Medical Doctor Profession and the Dentist Profession of $5^{\text {th }}$ of December 1996 (with later amendments) [1], Act of Pharmaceutical Law of $6^{\text {th }}$ of October 2001 [2], Regulation of the Minister of Health and Welfare of $11^{\text {th }}$ of May 1999 [3]. All regulations comply with the most important international guidelines formulated in: the Helsinki Declaration, the International Ethical Guidelines for Bioethical Research Involving Human Subjects (issued by the Council for International Organization of Medical Sciences), the guidelines of Good Clinical Practice, as well as legal regulations binding in Poland.

There are 54 Bioethical Committees in Poland and their activities depend on the main tasks of the institutions. The 24 appointed at the Regional Medical Councils mainly evaluate projects related to a new drugs pre-registration process, the 19 Committees at the Research Medical Institutes approve research projects concerning new therapy, diagnostics and monitoring methods, while those located at Medical Universities cover the whole spectrum: pharmacology, diagnostics, therapy research and pre-registration drug evaluation.

The Ministry of Health and Welfare supports the European Human Biomonitoring Programme, and Prof. Marek Jakubowski, the Nofer Institute of Occupational Medicine is the national work package leader. Within the framework of the pilot project, the application for bioethical evaluation will be submitted to the Bioethical Committee at the Nofer Institute of Occupational Medicine in Lodz.

\section{The Nofer Institute of Occupational Medicine (NIOM)}

The Nofer Institute of Occupational Medicine (NIOM), Lodz, Poland, was founded in 1954. During a period of more than five decades the institute has evolved from a small unit at the Medical University of Lodz into an independent complex research and development centre with activities covering various areas of occupational and environmental health. The activities of the Nofer Institute have gained considerable significance at both national and international levels. During the socioeconomic transition of the Central and Eastern European countries, the Institute has actively participated in the process of restructuring the occupational health services and prepared drafts of new legal acts on Occupational Health Service, chemical safety, social insurance system, etc [6].

The major research areas of the Nofer Institute of Occupational Medicine are:
- occupational medicine, environmental health, public health, occupational hygiene, radiation protection (ionising and non-ionising radiation)

- occupational pathology, prevention of occupational and work-related diseases with special regard to occupational allergy, diagnostics and treatment of acute poisonings

- toxicology, including toxicometry, toxicity assessment of chemicals and methodology of exposure assessment of chemical hazards in work environment

- epidemiology of occupational diseases and other health effects of exposure to physical, chemical and psychosocial hazards

- assessment of health risks from environmental exposure to hazardous agents

- physiology, psychology, sociology of work and ergonomics

- health promotion in the workplace

- management and economics of occupational health services

- health-based criteria of vocational selection and capability for work

The Bioethical Committee at the Nofer Institute of Occupational Medicine is appointed by the Internal Ordinance of the Director of NIOM for the period of three years and performs its functions until a new committee is appointed for the next term. Of its 13 members eight are medical doctors chosen among the researchers at NIOM according to their professional competence and experience in the field of research, while five are experts, independent of NIOM, with academic competence in theology, philosophy, pharmacy, law and health care service.

The decisions of the Committee concerning expressing opinion about the research projects are taken in the form of the resolution made by a secret ballot and only the votes for (a yes) or against (a no) the project can be approved [7].

The major topics of the applications submitted for ethical evaluation within the Bioethical Committees at NIOM are: a) development of new diagnostic methods for occupational diseases, b) development and validation of new biomarkers of exposure to chemicals both in the occupational setting and under experimental conditions (human volunteer studies), c) validation of usefulness of some 
Table I: Statistics of Activity of the Bureau of the Inspector General for Personal Data Protection - according to [10]

\begin{tabular}{|c|c|c|c|c|c|}
\hline \multirow[b]{2}{*}{ Type of Activity } & & & \multicolumn{3}{|c|}{ YEAR } \\
\hline & & & 2005 & 2006 & 2007 \\
\hline \multirow[t]{3}{*}{ Sent to the Inspector General } & \multicolumn{2}{|c|}{ Inquiries concerning the binding Act and its interpretation } & 2821 & 2228 & 1298 \\
\hline & \multicolumn{2}{|c|}{ Complaints } & 979 & 712 & 796 \\
\hline & \multicolumn{2}{|c|}{ Bills submitted for opinion } & 327 & 265 & 348 \\
\hline \multicolumn{3}{|c|}{ Inspections conducted by the Inspector General } & 119 & 108 & 167 \\
\hline \multirow[t]{7}{*}{ Decisions } & \multicolumn{2}{|c|}{ Jurisprudence, Legislation and Complaints Department * } & & 38 & 280 \\
\hline & \multicolumn{2}{|c|}{ Legal Department } & 6 & 7 & - \\
\hline & \multicolumn{2}{|c|}{ Inspection Department } & 98 & 101 & 130 \\
\hline & \multirow[t]{3}{*}{ Registry Department } & Refusal of registration & 123 & 215 & 173 \\
\hline & & Discontinuation of registration proceedings & 78 & 50 & 40 \\
\hline & & Removal from the nationwide registry of personal data filling system & 181 & 533 & 148 \\
\hline & \multicolumn{2}{|c|}{ Complaints Department } & 336 & 319 & - \\
\hline \multicolumn{3}{|c|}{ Total } & 822 & 1263 & 771 \\
\hline \multicolumn{3}{|c|}{ Notification of committed offences } & 52 & 15 & 18 \\
\hline \multirow[t]{2}{*}{ Files } & \multicolumn{2}{|c|}{ Submitted for registration } & 5344 & 4743 & 4850 \\
\hline & \multicolumn{2}{|c|}{ Registered } & 3175 & 3610 & 2598 \\
\hline
\end{tabular}

The possibility of removal from the nationwide registry of personal data filing systems was established as a result of the amendment to the Act on the Personal protection Data (Article 44, active I May 2004).

* - The Legal Department and the Complaints Department ceased to exist as of 10 November 2006. As a result of organizational changes, that is the combination of these two departments, the Jurisprudence, Legislation and Complaints Department was established.

biomarkers of effect (epidemiological studies), d) assessment of health risks from environmental exposure to hazardous agents.

Some examples of applications recently submitted to the Bioethical Committee at NIOM are:

"Night-shift work melatonin metabolism and breast cancer risk factors in nurses", "Dietary exposure to PAHs and DNA damage", "Usefulness of molecular biology techniques for oxidative stress assessment in breast cancer patients", Environmental exposure assessment of populations with different level of Methyl mercury intake".

The table on the Ethics Committees in Poland developed by ESBIO is presented in Additional file 1.

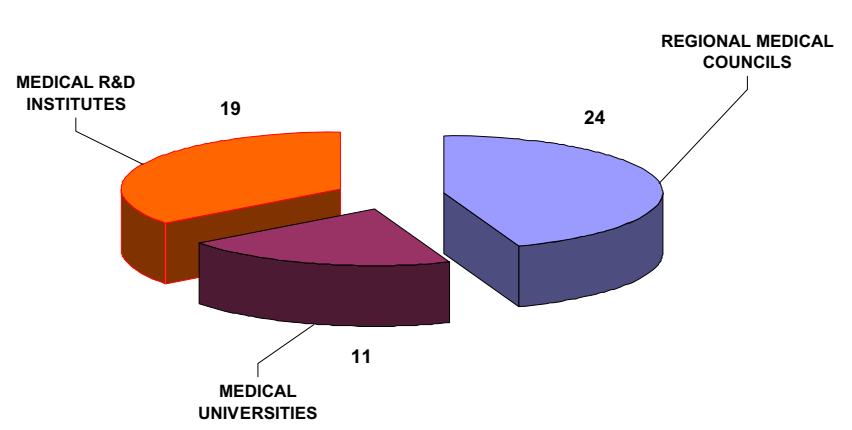

Figure I

Bioethical Committees in Poland.

\section{Personal data protection}

Provisions for regulating personal data processing were introduced in Polish legislation by the Act of Personal Data Protection of 29th of August 1997 (with later amendments) [8]. This Act fulfils the Directive 95/46/EC of the European Parliament and of the Council.

According to article 12 of the Act the duties of the Inspector General are: 1) to ensure the compliance of data processing with the provisions of the act of protection of personal data; 2) to issue administrative decisions and consider complaints with respect to the enforcement of the regulations on the protection of personal data; 3 ) to maintain the register of data filing systems and provide information of the registered data filing systems; 4) to issue opinions on draft laws and regulations with respect to the protection of personal data; 5) to initiate and undertake activities aimed at more efficient protection of personal data; 6) to participate in the work of international organisations and institutions involved in personal data protection [9].

The Act of Personal Data Protection states that informed consent must always be obtained from the data subject prior to processing of his or her personal data. Sensitive information may be processed upon written consent given by the data subject. Sensitive information is information on racial or ethnic origin, political opinions, religious or philosophical beliefs, religious, political party or trade-union membership, health records, genetic code, addictions or sexual life. 
The Inspector General for Personal Data Protection participates in the work of international organizations [10]:

- co-operates with international organisations involved in the protection of data,

- participates as an observer in the Working Party established on the basis of Article 29 of the Directive 95/46/EC of the European Parliament and of the Council of $24^{\text {th }}$ of October 1995 of the protection of individuals with regard to the processing of personal data and on the free movement of such data,

- appoints members of the Joint Supervisory Body of Europol (JSB Europol) and their alternates and nominates the candidates for a member of the Appeals Committee and his/her alternate,

- participates as an observer in the meetings of Joint Supervisory Authority of Schengen (JSA Schengen),

- participates as an observer in the meetings of Joint Supervisory Authority Customs (JSA Customs),

- co-operates with other countries' commissioners for data protection.

The Table on data protection in Poland developed by ESBIO is presented in Additional file 2.

The main tasks of the IGPD are registration of files, inquiries concerning the Act and its interpretation, and complaints. The last months of the year appear more active with most data submitted for registration and inquiries.

As shown in a Table 1 there are about. 5000 files submitted for registration per year while around 3000 per year are registered. The number of inquiries concerning the interpretation of the Act has decreased with $50 \%$ within the last 2 years.

The processing of personal data in violation of the Act may result in a ban of processing the data. Moreover, such unlawful processing is a crime, thus the management of the company which is not fulfilling all obligations may be subject to a fine, a limitation of liberty (such limitation may involve a prohibition on changing residence without the court's consent or an obligation to render social services for a period of up to one year), or imprisonment for up to three years [10].

\section{Conclusion}

Polish regulations comply with most of the EU and international rules with respect to ethical issues and personal data protection. Poland does not have a Central Ethics
Committee as in other EU member states. There are 54 independent Bioethical Committees in Poland which regards the respect for the dignity of a human being as superior to scientific aims of research.

\section{Competing interests}

The authors declare that they have no competing interests.

\section{Additional material}

\section{Additional file 1}

Overview: RECs in Poland

Click here for file

[http://www.biomedcentral.com/content/supplementary/1476-

069X-7-S1-S4-S1.doc]

\section{Additional file 2}

Overview: Data protection in Poland

Click here for file

[http://www.biomedcentral.com/content/supplementary/1476-

069X-7-S1-S4-S2.doc]

\section{Acknowledgements}

This paper was prepared within the ESBIO project - co-funded by the European Commission within the Sixth Framework Programme (2002-2006). The editorial assistance of Mrs. Vibeke Munk, Institute of Public Helath, University of Copenhagen is gratefully acknowledged.

This article has been published as part of Environmental Health Volume 7 Supplement I, 2008: Ethics and communication in human biomonitoring: European perspectives. The full contents of the supplement are available online at http://www.ehjournal.net/supplements/7/SI.

\section{References}

I. The Act of the medical doctor profession and the dentist profession of $5^{\text {th }}$ of December 1996 - unified text. Journal of Laws No. 226, item 1943 with later amendments [Ustawa o zawodzie lekarza i lekarza dentysty z 5 grudnia 1966 - tekst jednolity] 2005.

2. The Act of Pharmaceutical Law of $6^{\text {th }}$ of October 2001 - unified text. Journal of Laws No. 53, item 533 with later amendments [Ustawa z dnia 6 wrzesnia 200 I. Prawo Farmaceutyczne. - tekst jednolity.] 2004.

3. The Regulation of the Ministry of Health and Welfare of I th of May 1999 concerning the detailed rules of appointment, financing and the mode of operation of bioethical committees. Journal of Laws No. 47, item 480 [Rozporzadzenie Ministra Zdrowia i Opieki Spolecznej z II maja 1999 w sprawie szczegolowych zasad powolywania, finansowania oraz trybu dzialania komisji bioetycznych] 1999.

4. The Regulation of the Ministry of Health and Welfare regarding the appointment of and rules of procedure of a Bioethics Appeals Committee. Journal of Regulations of the Ministry of Health and Welfare No. 8, item 47 and No. 134, item 8I [Rozporzadzenie Ministra Zdrowia i Opieki Spolecznej o powolywaniu i zasadach funkcjonowania Komisji Odwolawczej] 200I.

5. The Regulation of the Ministry of Health and Welfare regarding the appointment of a Bioethics Appeals Committee. Journal of Regulations of the Ministry of Health No. 7, item 35 [Rozporzadzenie Ministra Zdrowia i Opieki Spolecznej o powolaniu Bioetyczej Komisiki Odwolawczej] 2002.

6. The Nofer Institute of Occupational Medicine [Instytut Medycyny Pracy im prof J. Nofera] [http://www.imp.lodz.pl]. 
7. The Internal Ordinance of the Director of the Nofer Institute of Occupational Medicine in Lodz on the appointment of Bioethical Committee of $10^{\text {th }}$ of August 2007. The Internal Ordinance of the Director of NIOM 6/2007 [Zarzadzenie Wewnetrzne Nr 6/2007 Dyrektora Instytutu Medycyny Pracy w Lodzi z dnia 10 sierpnia 2007r. w sprawie powolania Komisji Bioetycznej] .

8. The Act of Personal Data Protection of 29th of August 1997 - unified text. Journal of Laws No. 101, item 926 [Ustawa o Ochronie Danych Osobowych - tekst jednolity] 2002.

9. The Ministry of Interior and Administration [Ministerstwo Spraw Wewnetrznych i Administracji] [http://www.mswia.gov.pl/].

10. The Bureau of the Inspector General for Personal Data Protection [Glowny Instektor Ochrony Danych Osobowych] [http:// www.giodo.gov.pl].

Publish with Bio Med Central and every scientist can read your work free of charge

"BioMed Central will be the most significant development for disseminating the results of biomedical research in our lifetime. "

Sir Paul Nurse, Cancer Research UK

Your research papers will be:

- available free of charge to the entire biomedical community

- peer reviewed and published immediately upon acceptance

- cited in PubMed and archived on PubMed Central

- yours - you keep the copyright 